\author{
Ксения Морозова \\ ORCID: 0000-0003-2911-5621
}

Самарский национальный исследовательский университет имени академика С.П. Королёва

Самара, Россия

\title{
Галерея мужских образов в рассказе А.К. Гольдебаева Галчонок ${ }^{1}$
}

https://doi.org/10.34739/clit.2021.15.10

\author{
Gallery of Male Characters in the Story \\ The Young Jackdaw by A.K. Goldebaev
}

The motif of the Apocalypse passes through all the works of the Samara writer A.K. Goldebaev (Semenov). But if in his early works he did not highlight the end of the world (It seems distant and therefore not so scary to the author), years later he realizes the seriousness of what is happening - death isapproaching. In the story The Young Jackdaw (In the Established Order), published in 1910 in the short story collection Knowledge, the writer starts a conversation about the fallen women. However, this topic is not the leading one, and the female characters are not central ones. In this article, the author attempts to reveal the true meaning of the work through the analysis of the system of male characters.

Keywords: A.K. Goldebaev, M. Gorky, stories collection Knowledge, story The Young Jackdaw (In the Established Order), motive of the Apocalypse, male characters, characters system

Имя самарского писателя и журналиста А.К. Гольдебаева (1863-1924) числится сегодня среди имён забытых писателей, весьма редко встречаясь в историко-литературных исследованиях и даже в справочной литературе. Между тем и личность, и творчество Гольдебаева оставили более или менее яркий след как в литературном процессе его времени, так и в творчестве писателей-современников.

${ }^{1}$ Статья подготовлена при поддержке гранта РФФИ, проект 20-312-90040 «Творчество А.К. Гольдебаева (Семёнова). Феномен “провинциального писателя" в русской литературе конца XIX - начала XX вв.». 
Гольдебаев состоял в переписке со многими из них, будучи лично или заочно знакомым с А.П. Чеховым, М. Горьким, В.Г. Короленко, А.И. Куприным, А.Р. Крандиевской и многими другими.

Первым исследователем, обратившим внимание на личность и писательство А.К. Гольдебаева, был известный учёный и специалист по творчеству Чехова - А.П. Чудаков. Сегодня литературное наследие и биография Гольдебаева находятся в центре исследовательского внимания доктора филологических наук, профессора кафедры русской и зарубежной литературы Самарского университета М.А. Перепелкина и его аспирантки К.И. Морозовой. Научным тандемом был изучен ряд опубликованных и неопубликованных произведений (весомая часть уникального архива хранится в Самарском литературном музее) писателя, в том числе и три варианта рассказа Галчонок (Установленным порядком!) - рукописный, машинописный и окончательный текст, опубликованный в «Знании»². Подобное текстологическое рассмотрение рассказа стало шагом к пониманию основ мировоззрения и логики художественного развития Гольдебаева. Следующим этапом было изучение творческих взаимоотношений Гольдебаева и А.М. Горького ${ }^{3}$, ставшего одним из наставников самарского писателя, дав ему несколько рекомендаций по улучшению некоторых произведений и опубликовав того самого Галчонка. Наконец, в рамках этой статьи будет рассмотрена поэтика рассказа с помощью изучения системы его главных героев.

1.

Для начала перескажем фабулу рассказа, которая достаточно проста. «Их было трое: Перфильев, Савось и Макмагон, - неразлучная компания собутыльников». Летом трое друзей брали пиво, закуски, девиц и отправлялись на лодке в рощу за рекой, а «зимой же проводили свои вечера в облюбованном ресторане, откуда, выпивши, наговорившись о печальных явлениях текущего дня, ехали к комулибо из знакомых», где пили, пели, танцевали, спорили

2 См.: М.А. Перепелкин, К.И. Морозова, Миг славы. Рассказ А. К. Гольдебаева «Галчонок» («Установленным порядком!»): от рукописи до публикации на страницах сборника «Знание», «Уральский филологический вестник» 2020, № 4, с. 137-157.

3 См.: К.И. Морозова, Рассказ А.К.Гольдебаева «Галчонок» («Установленным порядком») на страницах горьковского «Знания», [в:] ХХХІХ Международная научная конференция «Горьковские чтения - 2020: Максим Горький в культуре XX-XXI вв, Нижний Новгород 2020, с. 291-296. 
о «переустройстве мира» (только Савось не любил танцы и избегал споров), играли в карты и флиртовали с барышнями. Оттуда навеселе троица установленным порядком отправлялась в бордель, точнее, в «солидный и приличный дом Акулины Михайловны». Каждую субботу гостей встречали три грации. Поля (Макмагон называл её «Галчонок») - девушка в общем-то некрасивая: «бледно-смуглая, как креолка, ни полная, ни худая, но с упругими, как резиновый мяч, молодыми формами»; Саша - «полная белотелая блондинка, с большими синими глазами, всегда улыбавшимися с какой-то овечьей наивностью» и Танька Чернообровенькая, «сущий бесёнок», появление которого значительно оживляло обстановку.

Каждая субботняя встреча проходила из раза в раз по одному сценарию: хозяйка дома оставляла девиц наедине с троицей холостяков для небольшого церемониала: девушки пели с гостями, танцевали, играли в фанты, а потом незаметно исчезали, оставляя трёх избранниц с их кредитными. Но однажды всё с самого начало пошло не по плану: не было никакого церемониала, разговор не клеился, девушки были молчаливые, растерянные, а Галчонок и вовсе не появлялась. Как выяснилось, Польку увёз один знакомый Василь Василича, поэтому эту ночь Савось провёл с Шарлотой. Галчонок, узнав про Шаролоту и Савося, разбила голову об сундук. Таня всю ночь проплакала из-за случившегося, но Антипыч не придал этому значения и спокойно спал. Во время следующей встречи троицу встретили так же холодно. Савось был настроен решительно отомстить Галчонку за «пропущенную» ночь, но его плану не суждено было сбыться: выяснилось, что девушка смертельно отравилась. Неожиданно в Савосе проснулись нежные чувства к самоубиенной. Он, Антипыч, Таня и ещё две девушки отправились на могилу к Галчонку. Макмагон остался с Сашей. Он хотел «поблагодарить её за что-то, молча извиниться перед ней в чём-то». Магмагон завёл разговор про обновление мира, которое будет возможным при изменении отношения мужчин к женщинам, когда они перестанут относиться к представительницам слабого пола, как к животному. После этого Магмагон ушёл, не дожидаясь возвращения приятелей. Завершается рассказ ночным разговором Саши и Тани. Девушка была расстроена, что после долгой и трудной дороги к могилке Галчонка никто из пришедших не проронил ни слова, а Савось и вовсе потешался над всем случившимся. 
Для понимания сюжета рассказа необходимо, в первую очередь, обратить внимание на систему персонажей.

2.

Несмотря на то, что названо произведение по имени одной из героинь, она всё же не является центральным персонажем. Женские образы, в принципе, выглядят несколько туманно. Мужские прописаны гораздо фактурнее.

Так, в весёлой троице друзей можно усмотреть отсылку к христианскому образу Святой Троицы - Живого Бога. Однако действия героев Гольдебаева таковы, что сакральный смысл профанируется и разрушается: персонажи живут по своим «канонам», прямо противоположным библейским заповедям.

Друзья видятся по будням, но основные их приключения приходятся на субботу, которая для истинного христианина «есть упокоение движения страстей, или совершённое бездействие их». Основное отличие субботнего богослужения от будничных проведение полной литургии.

Гольдебаевская троица «установленным порядком» своей религии отправляется в «церковь», а точнее, в «приличный дом Акулины Михайловны» для проведения «полной литургии» - на «ночлег к девицам». Как Божественная литургия начинается с проскомидии (приготовление хлеба и вина для таинства Причащения), так и «литургия» гольдебаевских персонажей начинается с «не менее четырёх бутылок на каждого вин дорогих, или же - по десяти бутылок пива»4.

Выбор такой жизненной стратегии гольдебаевские герои аргументируют просто: «кто Богу не грешен?». С одной стороны, они, чувствуя неизбежно скорую кончину мира, решают провести оставшееся время так, как хочется им. С другой стороны, приятели всё же надеются, что смогут как-то спасти себя от грядущих перемен. Понимая, что существующая религия их не защитит, они создают свою. Герои уверены, жизнь установленным ими порядком позволит всё контролировать. Однако сами же герои его и нарушают, пропуская одну субботу в доме Акулины Михайловны, что приводит к разрушению созданного ими микромира.

4 А. Гольдебаев, Галчонок, «Сборник товарищества „Знание“» 1910, № 29, с. 14. 
Сосредоточим же исследовательское внимание на каждом из «Лиц» гольдебаевской «Святой Троицы».

\section{3 .}

«Все трое были холосты и ещё молоды. Самому старшему их них, Перфильеву - Антипычу, по товарищеской кличке - не было ещё и тридцати пяти, Савось же переживал всего двадцать четвёртую зиму и был лет на пять моложе Макмагона»5. Галерея мужских образов выстраивается в соответствии с фольклорными традициями, где центральными героями выступают три брата - старший, средний и младший. Однако классическая формула, согласно которой младший брат, как правило, глупый, невезучий или ленивый в итоге становится самым счастливым, в рассказе Гольдебаева не работает.

1) Савось - младший в компании и вместе с тем самый несчастный и жестокий, он выступает своего рода антагонистом совестливого Макмагона. Но именно образ Савося вызывает особый интерес у Гольдебаева. Писатель создаёт не только его статический (описание черт лица и фигуры, роста, цвета глаз, волос и т.д.), но и динамический портрет (описание мимики, жестов, походки, тембра голоса, речи и т.д.). Как отмечал М.М. Бахтин,

Наружность нельзя брать изолированно по отношению к словеснохудожественному творчеству; некоторая неполнота чисто живописного портрета здесь восполняется целым рядом моментов, непосредственно примыкающих к наружности, малодоступных или вовсе недоступных изобразительному искусству: манеры, походка, тембр голоса, меняющееся выражение лица и всей наружности в те или иные исторические моменты жизни человека, выражение необратимых моментов события жизни в историческом ряду ее течения, моменты постепенного роста человека, проходящего через внешнюю выраженность возрастов; образы юности, зрелости, старости в их пластически-живописной непрерывности - моменты, которые можно обнять выражением: история внешнего человека ${ }^{6}$.

Гольдебаев описывает Савося так:

5 Ibidem, c. 4.

6 М. Бахтин, Автор и герой. К философским основам гуманитарнъх наук, Санкт-Петербург 2000, с. 61-62. 
Повыше среднего роста, стройный, курчавый, черноусый, с высокими чёрными бровями, с матово-белым лицом строго обрисованного овала, Савось был выдающийся красавец. Независимое выражение, открытый взгляд карих глаз под длинными ресницами, твёрдая поступь, напоминавшая Макмагону Каменного гостя - всё это придавало молодому красавцу оригинальность истукана, чопорного и холодного. Одевался Савось в поддёвку, высокие сапоги, шаровары; носил косоворотки 7 .

Бледность персонажа указывает на его «спиритуально-неземной характер»8 в «отрицательном демонологическом плане»9. Даже Антипыч называет в письме своего товарища бесом: «Мне скучно, беc!».

Демоническое, бесовское начало Савося проявляется в том, что он постоянно пытается соблазнить кого бы то ни было на грех. Например, он первым затевает пьянку («Савось нагнулся под стол, нащупал там бутылку, встряхнул её, нашёл пустоту и... „Изобразил бы ты?”, - закончил он изыскания. Кряхтя, смеясь и поругиваясь, Антипыч отправил приказчика за водкой» ${ }^{10}$ ) и инициирует субботнее посещение дома Акулины Михайловны взамен пропущенного визита:

Пока Савось мастерски вышибал пробку, Антипыч кивнул на него Магмагону.

- А вот он просится туда сегодня. - «Манкируем», - говорит, «одну субботу пропустили... Нехорошо» - говорит ${ }^{11}$. (...) Безжалостно откровенный Савось отзывался просто:

- Будет ломаться-то, Тартюф Иваныч! Пей-ка, да едем скорее. Двенадцатый уж, - какого ты чёрта, собственно говоря!12

Но самый греховный его поступок - пусть и неосознанное, но подталкивание Поли-Галчонка к самоубийству. Смерть девушки, казалось, послужила для него своеобразным катарсисом. Узнав о случившемся, молодой человек принялся истошно рыдать:

\footnotetext{
7 А. Гольдебаев, Галчонок..., op. cit., с. 8.

${ }^{8}$ М. Вайскопф, Влюбленный демиург: Метафизика и эротика русского романтизма, https://www.litres.ru/mihail-vayskopf/vlublennyy-demiurg-metafizika-i-erotika-russkogoromantizma-2/chitat-onlayn/ [ дата доступа: 28.10.2020].

9 Ibidem.

${ }^{10}$ А. Гольдебаев, Галчонок..., оp. cit., с. 8.

${ }^{11}$ Ibidem, c. 10.

${ }^{12}$ Ibidem, c. 5 .
} 
Савось приподнял с лежащих рук лицо, облитое слезами, красное, исполосованное белыми пятнами. Губы у него всё ещё дрожали.

- Спа-ать! - воскликнул он с горьким упрёком. - Могу ли я, батенька мой, спать?!..

И, качая головой, медленно с рыдающими возвышениями, продекламировал звучным, проникновенным баритоном:

- «Спи, кто может... Я спать не могу!..»13.

На самом деле, такая бурная реакция на весть о смерти Галчонка не была искренней: в этот трагический момент он вспомнил строки стихотворения Н.А. Некрасова Ръцарь на один час, превратив тем самым всё происходящее в фарс.

Он вытянул руки по столу и продолжил ещё трогательнее:

- «В эту ночь я хотел бы рыдать на могиле далёкой, где лежит моя бедная»...

Дрожащие губы замерли...

- Могилу мне, могилу! - воскликнул он, поднимаясь. - Укажите мне, отведите меня на могилу моего Галчонка!.. Покажите, где её схоронили! 14

Кроме этого, Гольдебаев отмечает, что, несмотря на молодой возраст, Савось давно потерял интерес к жизни.

Крестьянин с. Кимры, Тверской губернии, Савось, покинул университет на первом же курсе - не сколько из-за активного участия в беспорядках, сколько из чувства солидарности, поступил к родному отцу, зажиточному чеканщику, в мастера, ел сазана с квасом, спал на нарах и в престольные праздники распевал с мастерами свои, тверские, песни. И когда его спрашивали, зачем всё это он делает, Савось независимо басил в ответ: «-А так мне нравится, батенька мой, собственно говоря!»15 А его панический страх перед женщинами порождал ненависть и презрение к ни в чём не повинным особам:

Несмотря на свою красоту и независимость, Савось был изумительно труслив с женщинами. Не смея вымолвить слова с ними, он надменно хмурил брови, сердито крутил густые усы и пользовался всеми возможностями, чтобы поскорее отступить с достоинством. За что и отчитывал женщин постоянным презрением: все они были, по мнению

\footnotetext{
13 Ibidem, c. 41.

14 Ibidem, c. 41.

15 Ibidem, c. 8.
} 
Савося, коварны, бесстыдны, продажны, навязчивы. В него влюблялись, разумеется, но - до первого свидания наедине: деревянная неподвижность и суровое молчание красавца обескураживало самую пламенную страсть, внушало стыд. Лучше было любоваться им издали ${ }^{16}$.

Очень точно характеризует Гольдебаев внутреннюю безжизненность и аморфность Савося, называя его «Каменным гостем». Аллюзия на персонажей драмы А.С. Пушкина Каменный гость (1830) подчёркивает в Савосе «холодность, амбивалентность, монументальность эстетический знак / случайность, мимолетность, легкомысленность духовный знак (Дон Гуан)»17 и «греховную отягощённость, материальность, реальность овеществления гордости, пагубность порока, падение в безверие - «каменный» - (статуя командора)»18. Кроме этого, усиливает в рассказе дух «извращённости и упадничества» ${ }^{19}$.

2) Пётр Антипыч Перфильев был старше всех в компании. Его фигура в рассказе ничем особо не примечательна - ни внешне («полнощёкий, рябой Антипыч, с пушком вместо волос на голове и грубыми щетинистыми усами под толстым носом»), ни внутренне. Его психологический портрет раскрывается посредством описания интерьера библиотеки, «почти не имевшей подписчиков»: «Две лампы на окнах освещали выставленные с прошлого лета книги, обложки которых выцвели, не соблазнив ничьего внимания» ${ }^{20}$, равно как и сам книготорговец.

Когда речь заходила о «солидном и приличном доме» Акулины Михайловны, возникающее чувство стыдливости Антипыч прикрывал иронией и говорил об обитательницах дома «насмешливо, разумеется, но с заметной теплотой, как о «наших собственных, неизменных». Книготорговец, пожалуй, единственный из троицы друзей нуждался в настоящих отношениях и семье: «Сказывался зрелый возраст: Антипыч охотнее, чем двое остальных, искал иллюзии постоянства. Сказывалось у него ещё нечто, чего те, двое, совершенно не обнаруживали». Весной правила дома изменились: теперь «гости освобождались от платы за ночь, но зато были обязаны потребовать не

\footnotetext{
${ }^{16}$ Ibidem, c. 8-9.

17 Е. Александрова, «Каменный гость». К проблеме понимания нравственно-эстетической концепции А. С. Пушкина, «Омский научный вестник» 2010, № 6 (92), с. 126.

18 Ibidem, c. 126.

19 Д. Благой. Социология творчества Пушкина, Москва 1929.

20 Ibidem, c. 7.
} 
менее четырёх бутылок на каждого вин дорогих, или же - по десяти бутылок пива». Такое нововведение било по карману приятелей, но Антипычу «это было даже по сердцу: являлась ещё большая иллюзия домашности, семейности при бесплатных ночах». А, узнав про своего знакомого, который как раз и купил ночь с Галчоноком, тем самым, спровоцировав трагедию, книготорговец неодобрительно заявляет: «Удивительно опустился человек! (...) Семейный, ведь... Трое ребятишек... Жена - такая милочка...».

3) Иван Васильевич Макмортон (по псевдониму Макмагон) является протагонистом рассказа. «Плотный, коренастый Макмагон с разовым лицом в чёрной бороде, подвижный, говорливый, всегда одетый со вкусом, являлся приятной противоположностью молчаливого демократа Савося, с его поддёвкой» ${ }^{21}$.

Макмагону была чужда сентиментальность Антипыча и наигранность Савося. С присущей ему хладнокровностью и прямолинейностью он видел то, чего не замечали другие и мог дать чёткое объяснение тому, что происходило в мире. Гольдебаев доверяет ему, поэтому своё пророческое заявление о будущем он вкладывает в уста литератора Макмагона:

(...) И придёт время (...) когда женщина затоскует уже сознательно, томимая стыдом своей второстепенной роли. Тогда лишь действительно обновится мир. Исчезнет разница концепций: мужчина, женщина; наступит жизнь, достойная человека, и люди забудут позор не только покупных ласк, но и брака, каким он был когда-то, -в наше подлое время. Ибо, что такое брак, законный и договорной союз двух интеллигентнейших современников, лучшей женщины с лучшим мужчиной, если не та же постыдная купля-продажа?! - «Он» делает историю и доставляет средства «ей»; она заведует гигиеной по Эрисману, педагогикой по Сикорскому, котлетами, бельём, доставляет «ему» интимные наслаждения и всегда очинённые карандаши... Но ещё хуже, если они меняются местами в современном браке!... И всё это от того, что мир делится на левых, трудящихся, и - правых, ликующих, праздно болтающих ${ }^{22}$.

Макмагон - единственный из друзей не отправляется на могилу к Галчонку. «Сантименты, поверьте мне! Да и кому это нужно?.. Надо

${ }^{21}$ Ibidem, c. 9 .

${ }^{22}$ Ibidem, c. 43-44. 
было раньше...», - так он объясняет свой отказ. Он чувствует за собой, как за представителем мужской половины общества, вину за трагедию. Есть ли вероятность, что после истории с Галчонком Макмагон рискнёт изменить мир к лучшему и спасти от гибели? К сожалению, нет. Он смирился с обстановкой и просто приспосабливается к ней.

Итак, Гольдебаев изображает перевёрнутый, десакрализованный мир, в центре которого - «Святая Троица», состоящая из друзей-аморалистов - Савося, Макмагона и Антипыча, которые как бы олицетворяют три Ипостаси Бога (Отец, Сын, Святой Дух). Именно поэтому в рассказе писатель уделяет большее внимание мужским образам, чем женским. Моделируя художественную действительность таким образом, Гольдебаев пытается предупредить читателя о неминуемом крахе мира, который не способны спасти ли любовь, ни вера в Бога.

\section{Литература}

Александрова Е., «Каменный гость». К проблеме понимания нравственноэстетической концепции А. С. Пушкина, «Омский научный вестник» 2010, № 6 (92), c. 125-128.

Бахтин М., Автор и герой. К философским основам гуманитарных наук, Санкт-Петербург 2000.

Благой Д., Социология творчества Пушкина, Москва 1929.

Вайскопф М., Влюбленный демиург: Метафизика и эротика русского романтизма, https://www.litres.ru/mihail-vayskopf/vlublennyydemiurg-metafizika-i-erotika-russkogo-romantizma-2/chitat-onlayn/ [дата доступа: 28.10.2020].

Гольдебаев А., Галчонок, «Сборник товарищества „Знание”» 1910, № 29, с. 2-46.

\section{References}

Aleksandrova E., «Kamennŷj host'». K probleme ponymanyja nravstvennoэstetyčeskoj koncepcyy A. S. Puškina, «Omskyj naučnŷj vestnyk» 2010, № 6 (92), s. 125-128.

Bachtyn M., Avtor y heroj. K fylosofskym osnovam humanytarnŷch nauk, SanktPeterburg 2000.

Blahoj D., Socyolohyja tvorčestua Puškina, Moskva 1929.

Vajskopf M., Vljublennŷj demyurh: Metafyzyka y erotyka russkoho romantyzma, https://www.litres.ru/mihail-vayskopf/vlublennyy-demiurg-metafizika-ierotika-russkogo-romantizma-2/chitat-onlayn/ [data odstupa: 28.10.2020].

Gol'debaev A., Halčonok, «Sbornyk tovaryščestva „Znanye”» 1910, № 29, s. 2-46. 